\title{
PENINGKATAN AKTIVITAS DAN HASIL BELAJAR MATEMATIKA MATERI BANGUN DATAR MENGGUNAKAN ALAT PERAGA GEOMETRI DATAR KELAS III SDN 008 SANGATTA SELATAN
}

\author{
Sunarti \\ Universitas Mulawarman \\ sunartidilan@gmail.com
}

\begin{abstract}
This researcher bertutuan to improve the activity and learning outcomes in mathematics through Materials Up Datat Props to the Geometry of the Flat in class III SDN 008 South Sangatta. This research is motivated by low activity mathematics learning outcomes of students class III SDN 008 South Sangatta. Subject this research is students class III SDN 008 South Sangatta which amounted to 20 students. This research type is Classroom Action Research (classroom Action). With research that use is the model Kemmis which includes the stages of planning, implementation of action, observation, and reflection. The instrument of data collection used is the observation sheet. The data analysis technique used is data analysis descriptive qualitative.

Based on the results of data analysis at cycle I of meeting I activity the students showed $30 \%$, meeting 2 shows 39\%, meeting 3 showed 47\%, the average value of student activity cycle I shows $42 \%$, classified as criteria low. After repair there was an increase in cycle II meeting I Activity the student demonstrates $80 \%$, meeting 2 shows $86 \%$, meeting 3 show that $92 \%$, the average value of students of cycle II showed $86 \%$, quite high criteria. This increase occurs where students always pay attention to his weaknesses and trying to memprbaikinya seemingly on the stages of the cycle that there is always an increase. Increased activity of students can also affect the improvement of student learning which indicates the average percentage of the first cycle $61 \%$, cycle II is $78 \%$. From the results of the research show that props up a flat geometry flat can increase the activity and learning outcomes in mathematics in class III SDN 008 South Sangatta. Keywords : Activities, Learning Outcomes, Teaching Aids
\end{abstract}

\begin{abstract}
ABSTRAK
Penelitian ini bertujuan untuk meningkatkan aktivitas dan hasil belajar matematika melalui Materi Bangun datat Alat Peraga Geometri datar di kelas III SDN 008 Sangatta Selatan. Penelitian ini dilatar belakangi oleh rendahnya aktivitas hasil belajar matematika siswa kelas III SDN 008 Sangatta Selatan. Subjek penelitian ini adalah siswa kelas kelas III SDN 008 Sangatta Selatan yang berjumlah 20 siswa. Jenis penelitian ini adalah Penelitian Tindakan Kelas. Dengan penelitian yang menggunakan adalah model yang Kemmis yang meliputi tahap perencanaan, pelaksanaan tindakan, dan observasi serta refleksi. Instrumen pengumpulan data yang digunakan adalah lembar observasi. Teknik analisis data yang digunakan adalah analisis data deskriftif kualitatif.

Berdasarkan hasil penelitian dapat disimpulkan bahwa peningkatan aktivitas dan hasil belajar dan analisis data pada siklus I menunjukkan $42 \%$, dengan kriteria rendah. Setelah dilakukan perbaikan terjadi peningkatan pada siklus II menunjukkan $92 \%$, nilai rata-rata siswa siklus II menunjukkan $86 \%$, tergolong kriteria tinggi. Peningkatan ini terjadi dimana siswa selalu memperhatikan kelemahannya dan berusaha untuk memperbaikinya terlihat pada tahapan-tahapan siklus yang selalu ada peningkatan. Peningkatan aktivitas siswa juga dapat berpengaruh terhadap peningkatan hasil belajar siswa yang menunjukkan persentase rata-rata siklus I 61\%, siklus II 78\%. Dari hasil penelitian menunjukkan bahwa alat peraga bangun datar geometri datar dapat meningkatkan aktivitas dan hasil belajar matematika di kelas III SDN 008 Sangatta Selatan.
\end{abstract}

Kata kunci : Aktivitas , Hasil Belajar, Alat Peraga 


\section{PENDAHULUAN}

Salah satu masalah yang dihadapi dunia pendidikan Indonesia adalah masalah lemahnya proses pembelajaran. Dalam proses pembelajaran peserta didik kurang didorong untuk mengembangkan kemampuan berpikir. Proses pembelajaran di dalam kelas diarahkan pada kemampuan peserta didik untuk menghafal informasi, otak dipaksa untuk mengingat dan menimbun berbagai informasi tanpa dituntut untuk memahami informasi yang diingatnya itu untuk menghubungkannya dengan kehidupan sehari-hari (Sanjaya. 2010:21).

Sebagaimana kita ketahui bahwa guru merupakan faktor yang sangat strategis dalam upaya meningkatkan keefektifan pembelajaran agar proses belajar mengajar bisa lebih bermakna dan dapat mencapai hasil yang optimal. Pembelajaran akan sangat efektif dan bermakna jika dengan pembelajaran tersebut, siswa menjadi lebih mudah dalam memahami pelajaran dan dengan pembelajaran itu pula siswa menjadi senang dan termotivasi untuk belajar serta tidak mudah jenuh.

Peningkatan mutu pelaksanaan pembelajaran di sekolah dilakukan dengan berbagai strategi, salah satu diantaranya melalui penerapan pendekatan pendidikan dan pelatihan berbasis kompetensi (competency based education and training). Pendekatan berbasis kompetensi

digunakan sebagai acuan dalam pengembangan kurikulum, pengembangan bahan ajar, pelaksanaan pembelajaran,dan pengembangan prosedur penilaian (Sanjaya. $2010: 27$ ).

Terkait dengan peingkatan aktivitas dan hasil belajar, matematika merupakan ilmu dasar yang sudah menjadi alat untuk mempelajari ilmuilmu yang lain. Oleh karena itu, mata pelajaran matematika telah dituangkan dalam kurikulum dari berbagai jenis dan tingkat jenjang pendidikan di sekolah- sekolah khusus untuk tingkat pendidikan sekolah dasar (SD), pendidikan matematika sangat berperang penting. Dengan belajar matematika di tingkat sekolah dasar siswa akan memiliki pengetahuan dasar matematika yang kuat untuk mempelajari matematika di tingkat sekolah lanjutan.

Menurut Jannah (2011:25) bahwa tidak semua materi mudah dicermati oleh siswa sehingga pada tahap-tahap awal dalam pengenalan konsep, pemakaian alat peraga atau alat bantu seringkali merupakan suatu kebutuhan yang tidak bisa dihindari. Selain itu, bahan ajar juga menjadi kebutuhan untuk menciptakan suasana belajar yang menyenangkan. Berbagai bentuk bahan ajar seperti alat peraga, media dan lembar kerja perlu dibuat untuk membantu siswa dalam belajar.

Guru selalu berupaya agar tujuan pembelajaran yang telah ditetapkan harus berhasil dicapai tidak dapat dipungkiri telah banyak yang dilakukan oleh guru untuk memaksimalkan kegiatan pembelajaran dalam rangka mencapai tujuan pembelajaran tersebut namun usaha yang telah ditempuh oleh guru tidak selalu memberikan hasil yang memuaskan. Dan hal itu akan menjadi tantangan bagi guru untuk meningkatkan proses pembelajaran yang lebih baik lagi dan dapat mencapai tujuan pendidikan yang telah ditetapkan.

rumusan masalah dalam penelitian ini adalah bagaimana peningkatan aktivitas guru, aktivitas siswa dan hasil belajar dalam pembelajaran matematika materi bangun datar menggunakan alat peraga geometri datar pada siswa kelas III SDN 008 Sangatta Selatan?

\section{KAJIAN PUSTAKA}

Belajar merupakan aktivitas yang dilakukan seseorang untuk mendapatkan perubahan dalam dirinya melalui pelatihan-pelatihan atau pengalamanpengalaman. Dengan demikian, belajar dapat membawa perubahan dengan si 
pelaku, baik perubahan pengetahuan, sikap maupun keterampilan.

Menurut Dahar (2007:12-13)

menyatakan bahwa belajar adalah sebagai suatu proses dimana suatu organisme berubah perilakunya sebagai akibat pengalaman. Jadi pengertian tersebut terdapat unsur pokok belajar, yaitu: (1) Belajar terjadi karena adanya proses; (2) Belajar ditandai dengan adanya perubahan perilaku; (3) Hasil belajar diperoleh dari pengalaman. Mengemukakan ciri-ciri perubahan tingka laku sebagai berikut: (1) perubahan bersifat internasional, dalam arti pengalaman yang diperoleh itu dengan sengaja dan disadari, diperoleh bukan seara kebetulan; (2) perubahan bersifat positif, dalam arti sesuai dengan yang diharapkan atau kriteria keberhasilan baik dipandang dari segi peserta didik maupun dari segi pendidik. Pembelajaran adalah proses interaksi peserta didik dengan guru dan sumber belajar pada suatu lingkungan belajar. Proses pembelajaran untuk setiap mata pelajaran harus fleksibel, bervariasi dan memenuhi standar. Pelaksanan proses pembelajaran terdiri dari 3 (tiga) tahapan yaitu pendahuluan, kegiatan inti dan penutup.

Dalam proses belajar sangat dibutuhkan adanya aktivitas, dikarenakan tanpa adanya aktivitas proses belajar tidak mungkin berlangsung dengan baik. Pada proses aktivitas pembelajaran harus melibatkan seluruh aspek peserta didik, baik jasmani maupun rohani sehingga perubahan perilakunya dapat berubah dengan cepat, tepat, mudah dan benar, baik berkaitan dengan aspek kognitif afektif maupun psikomotor (Hanafiah, 2010:23).

Hasil belajar meliputi bertambahnya pengetahuan dan keterampilan, belajar mengajar dengan membawa suatu perubahan laku seseorang sehingga pencapaian tujuan belajar adalah memperoleh hasil belajar yang baik. Oleh karena itu, sebagai pendidik harus dapat menyampaikan tujuan belajar dengan baik. Dimyati (2012 :37) berpendapat bahwa hasil belajar adalah kemampuan yang diperoleh siswa setelah melalui kegiatan belajar.

Hasil belajar dapat dikatakan sebagai suatu umpan balik dari kegiatan proses belajar mengajar. Seseorang dapat dikatakan berhasil dalam pelaksanaan belajar apabila telah terjadi perubahan tingkah laku dalam diri orang tersebut. Menurut Djamarah (2009:96) indikator dari proses belajar mengajar dianggap berhasil adalah; (1) Daya serap terhadap bahan pelajaran yang diajarkan mencapai prestasi tinggi, baik secara individual maupun kelompok; (2) Perilaku yang digariskan dalam tujuan belajar telah dicapai anak didik baik secara individual maupun kelompok.

\section{METODOLOGI PENELITIAN}

Penelian ini dilaksanakan di SDN 008 Sangatta Selatan, pada tahun ajaran 2018/2019 ketika sekolah tersebut sedang melaksanakan kegiatan belajar mengajar di semester genap. Metode yang digunakan dalam penelitian ini merupan Penelitian Tindakan Kelas (PTK), desain penelitian dalam pembelajaran memiliki empat unsur, yaitu unsur karakteristik siswa, unsur tujuan yang ingin dicapai, unsur metode dan kegiatan pembelajaran, unsur evaluasi.

Prosedur dan rancangan tindakan kelas ini terdiri dari siklus-siklus yang dilaksanakan berulang dan berkelanjutan dengan harapan adanya perubahan kearah peningkatan hasil yang diinginkan dari siklus pertama kesiklus selanjutnya. Pengamatan (observer) melakukan observasi terhadap kegiatan yang dilaksanakan sebagai bahan diskusi untuk tujuan perbaikan proses pembelajaran. Selain itu, dilakukan pula wawancara siswa untuk mengetahui kelemahan dan kesulitan yang dialami siswa. Sedangkan untuk mengetahui 
partisipasi siswa dalam kegiatan belajar mengajar dilakukan pengamatan terhadap keterlibatan siswa selama kegiatan belajar berlangsung. Berdasarkan hasil observasi, hasil belajar dan wawancara dengan siswa, peneliti dan observer melakukan diskusi untuk mengkaji kelemahan guna meningkatkan proses pembelajaran (refleksi).

Teknik pengumpulan data dilakukan dengan tes dan observasi sedangkan tekhnik analisis data yang digunakan adalah perhitungan rata-rata nilai dalam bentuk nilai. Observasi penilaian pelaksanaan dinyatakan berhasil apabila mengalami peningkatan mutu pembelajaran oleh guru atau hasil pengamatan mencapai persentase $\geq 70 \%$; (3) Hasil belajar secara individual siswa mencapai $\mathrm{KKM} \geq 65$ (sesuai dengan KKM di sekolah), dan hasil belajar secara kelompok mencapai . 65\% untuk keseluruhan siswa di dalam kelas.

\section{HASIL PENELITIAN DAN PEMBAHASAN}

Aktivitas guru siklus I dan siklus II dalam melakukan observasi peneliti dibantu oleh teman sejawat untuk mengamati aktivitas guru selama proses pembelajaran berlangsung.

hasil observasi aktivitas guru dari pertemuan pertama hingga pertemuan ketiga diperoleh persentase $48 \%$ pada pertemuan pertama rata - rata aspek penilaian 1,57 atau sebesar 39,3\% dan pertemuan kedua rata - rata aspek penilaian adalah 2 atau sebesar $50 \%$ serta pada pertemuan ketiga rata - rata aspek penilaian 2,21 atau sebesar 55,6\% berdasarkan kreteria yang telah ditetapkan diketahui bahwa aktivitas guru dalam siklus I di peroleh persentase $48 \%$ termasuk dalam kategori sangat rendah, sehingga perlu di evaluasi aspek mana yang perlu diperbaiki pada siklus II.
Tebel Hasil Observasi Aktivitas Guru dalam Proses Pembelajaran Geometri Datar

\begin{tabular}{|l|l|c|c|c|}
\hline No & \multirow{2}{*}{$\begin{array}{c}\text { Aspek } \\
\text { Penilaian }\end{array}$} & \multicolumn{3}{|c|}{ Pertemuan } \\
\cline { 3 - 5 } & I & II & III \\
\hline 1 & Penadahuluan & 13 & 13 & 13 \\
\hline 2 & Kegiatan Inti & 22 & 24 & 25 \\
\hline 3 & Penutup & 20 & 11 & 12 \\
\hline Jumlah & 44 & 48 & 53 \\
\hline Rata - Rata & 3.1 & 3,4 & 3,7 \\
\hline \multicolumn{2}{|l|}{ Prosentase } & $75 \%$ & $86 \%$ & $95 \%$ \\
\hline $\begin{array}{l}\text { Rata - Rata } \\
\text { Keseluruhan }\end{array}$ & \multicolumn{4}{|c}{$86 \%$} \\
\hline
\end{tabular}

Sumber: Data Primer

pertemuan pertama hingga pertemuan kedua diperoleh rata-rata $86 \%$ pada pertemuan pertama hasil aktivitas guru dalam pembelajaran matematika khususnya materi bangun datar menggunakan alat peraga geometri sebesar $75 \%$ meningkat sebesar $14,6 \%$ menjadi $86 \%$ pada pertemuan kedua dan pertemuan ketiga meningkat sebesar $10,5 \%$ menjadi $95 \%$. Menurut kreteria yang telah ditentukan aktivitas guru secara keseluruhan pada siklus II diperoleh rata-rata $86 \%$ termasuk kategori tinggi.

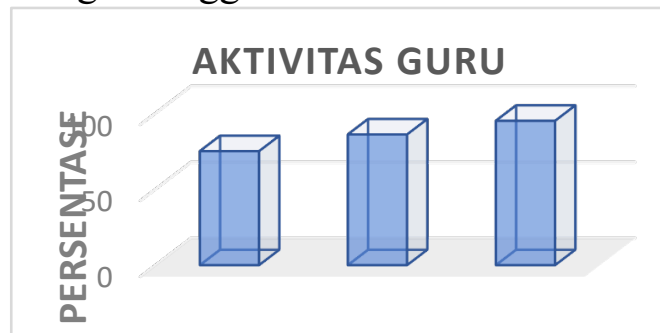

Gambar: Diagram Batang Aktivitas Guru

Berdasarkan diagram pada gambar 4.2 menunjukkan bahwa aktivitas guru dalam proses pembelajaran geometri datar di Siklus II pada pertemuan pertama sebesar $78 \%$ meningkat pada pertemuan kedua sebesar $10,2 \%$ menjadi $86 \%$ dan pada pertemuan ketiga meningkat sebesar $10,4 \%$ menjadi $95 \%$ menurut kiteria yang telah ditentukan aktivitas guru secara keseluruhan pada siklus II di 
peroleh rata-rata $86 \%$ termasuk kategori tinggi.

Aktivitas siswa pada pertemuan pertama persentase aktivitas siswa sebesar $30 \%$. pertemuan kedua persentase aktivitas siswa sebesar 39\% dan pertemuan pertana persentase aktivitas siswa sebesar $47 \%$ dan ratarata persentase aktivitas siswa pada siklus I sebesar $42 \%$ termasuk dalam kategori sangat rendah. Pada siklus II pertemuan pertama $80 \%$ meningkat sebesar $75 \%$ pertemuan kedua menjadi $86 \%$ dan pertemuan ketiga meningkat menjadi 92\%. Aktivitas siswa secara keseluruhan pada siklus kedua diperoleh rata-rata $86 \%$ termasuk dalam kategori tinggi.

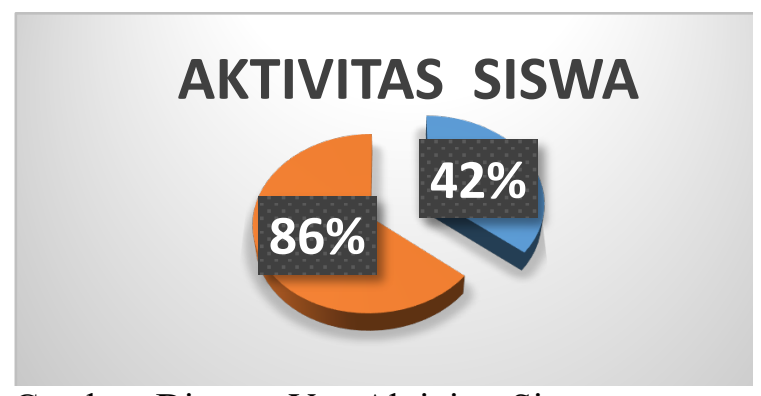

Gambar: Diagran Ven Aktivitas Siswa

Hasil belajar siswa pada formatif pertama nilai terendah 42 nilai tertinggi 80 , hasil belajar siswa pada formatif kedua nilai terendah 47 dan tertinggi 80 sedangkan hasil belajar siswa pada post tes terendah 51 dan tertinggi 84. Dari akhir siklus I terdapat pada siswa 9 tuntas dan 11 siswa tidak tuntas. Hasil belajar siklus 1 belum mencapai ketuntasan masih jauh dari KKM yang ditetapkan sebesar 65 dan ketuntasan kalsikal 65\%.
Tabel Hasil Pembelajarn Siswa Siklus II

\begin{tabular}{|l|c|c|c|}
\hline Keterangan & $\begin{array}{c}\text { Formatif } \\
1\end{array}$ & $\begin{array}{c}\text { Formatif } \\
2\end{array}$ & $\begin{array}{c}\text { Post } \\
\text { Tes }\end{array}$ \\
\hline Tinggi & 92 & 98 & 100 \\
\hline Rendah & 55 & 58 & 61 \\
\hline Siswa Tuntas & 15 & 17 & 19 \\
\hline Persentase & $75 \%$ & $85 \%$ & $95 \%$ \\
\hline $\begin{array}{l}\text { Siswa Tidak } \\
\text { Tuntas }\end{array}$ & 5 & 3 & 1 \\
\hline Persentase & $25 \%$ & $15 \%$ & $5 \%$ \\
\hline Rata - Rata & \multicolumn{3}{|c|}{$78 \%$} \\
\hline
\end{tabular}

Nilai $\mathrm{t}$ formatif pertama terendah 55 , tertinggi 95. Formatif 2 terendah 58, tertinggi 98 dan post tes terendah 61 tertinggi 100. Dari rata-rata kelas sudah diatas KKM pelajaran matematika sebesar $78 \%$ dengan peningkatan sebesar $28 \%$ dari siklus I.

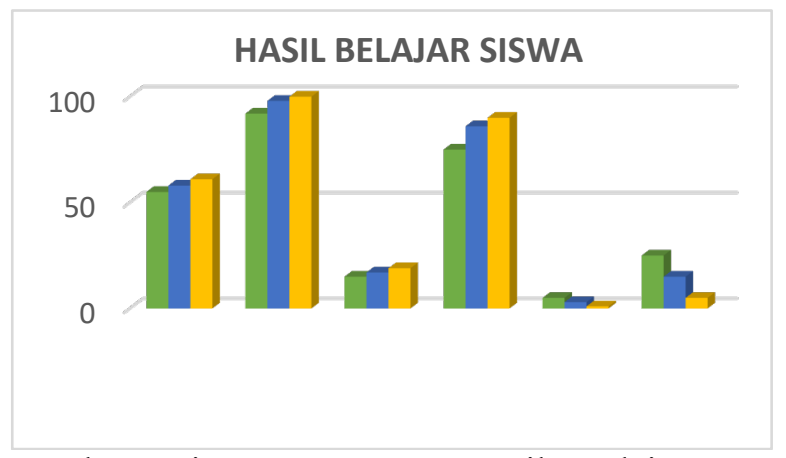

Gambar Diagram Batang Hasil Belajar Siswa

Diagram batang pada gambar 4.8 menunjukkan nilai rata-rata $78 \%$, formatif pertama terdapat 15 siswa tuntas yaitu sebesar 75\%. Formatif kedua sebanyak 17 siswa tuntas yaitu sebesar $85 \%$ serta post tes 19 siswa tuntas yaitu sebesar 95\% tuntas. Rekapitulasi hasil belajar siswa dalam pembelajaran pada siklus II sebesar $78 \%$ dengan kategori tinggi hal ini menunjukkan bahwa penelitian siklus II dinyatakan berhasil atau tuntas karena nilai rata-rata kelas secara klasikal diatas $70 \%$ begitu juga cara individu diatas KKM yakni 65. 
Tujuan

pembelajaran

menggunakan alat peraga geometri datar adalah untuk melatih siswa dalam belajar untuk menemukan suatu ide baru dan relasinya dengan konsepkonsep yang telah diketahuinya. Dalam konsep ini siswa harus mendapatkan kesempatan dalam mendapatkan pengalaman yang integral dari suatu yang konkrit sampai kepada yang abstrak.

Penelitian tindakan kelas yang mengutamakan proses diamati keterlibatan guru dan siswa dalam proses pembelajaran, meskipun hasil akhir yang diperlukan adalah ditunjukkan bagi kepentingan siswa. Penelitian tindakan kelas sebagai upaya untuk mengatasi permasalahan dalam kelas yang nantinya diharapkan dapat membantu guru itu sendiri.

Aktivitas siswa adalah kegiatan siswa selama mengikuti proses pembelajaran di kelas. Dengan peningkatan aktivitas siswa dalam proses pembelajaran akan meningkatkan pemahaman siswa tersebut dan berdampak pada peningkatan hasil belajrnya.

Peningkatan kemampuan guru dalam pembelajaran juga diamati, karena dengan aktivitas pembelajaran yang meningkat, kemampuan guru dalam menjalankan proses pembelajaran juga meningkat sehingga berdampak pada peningkatan aktivitas dan hasil belajar siswa. Hal ini karena proses pembelajran merupakan interaksi antara guru dengan siswa dikelas. Aktivitas dalam proses belajar mengajar merupakan rangkaian kegiatan yang meliputi keaktifan siswa dalam mengikuti pelajaran, bertanya hal yang belum jelas, mencatat, mendengar, berpikir, membaca dan segala kegiatan yang dilakukan, yang dapat menunjang prestasi belajar (Sardiman, 2010 : 99).

Di tinjau dari aktivitas guru dengan menggunakan pembelajaran alat peraga geometri datar mengalami peningkatan setiap siklusnya. Hal ini dapat diketahui dari data lembar observasi aktivitas guru. Pemahaman atau membiasakan guru dalam menerapkan pembelajaran alat peraga geometri datar pada siklus I sudah mulai terlihat ada perbaikan tapi masih ada aspek yang masih kurang dan akan diperbaiki disiklus II, diharapkan guru sudah terbiasa menerapkan pembelajaran menggunakan alat peraga geometri datar. Kelebihan penggunaan alat peraga adalah menumbuhkan minat belajar siswa karena pelajaran menjadi lebih menarik, memperjelas makna bahan pelajaran sehingga siswa lebih mudah memahaminya, metode mengajar akan lebih bervariasi sehingga siswa tidak akan mudah bosan dan membuat lebih aktif melakukan kegiatan belajar seperti mengamati, melakukan dan mendemontrasikan (Sudijono, 2012:8).

Akivitas siswa dalam proses pembelajaran membawa dampak terhadap meningkatkan hasil belajarnya. Dengan meningkatnya aktivitas siswa ditandai dengan salah satu aspek yakni partisipan aktif siswa dalam pembelajaran, aktivitas pembelajaran siswa pada penggunaan alat peraga dan mendengarkan penjelasan guru dari aspek tersebut bisa berpengaruh terhadap pemahaman siswa pada pelajaran yang diberikan, hal ini dapat diketahui dari hasil pembelajaran siswa yang semakin meningkat.

Hasil belajar siswa terbagi dalam tiga tahap yaitu formatif pertama yaitu sebesar $75 \%$, formatif kedua sebesar $85 \%$ serta post tes sebesar 95\% tuntas. Rekapitulasi rata-rata kesekuruhan hasil belajar siswa dalam pembelajaran pada siklus II sebesar $78 \%$ dengan kategori tinggi hal ini menunjukkan bahwa penelitian siklus II dinyatakan berhasil atau tuntas karena nilai rata-rata kelas secara klasikal 
diatas $70 \%$ begitu juga cara individu diatas KKM yakni 65 .

\section{KESIMPULAN}

Aktivitas guru dalam pembelajaran matematika tentang materi bangun datar menggunakan alat peraga geometri datar mengalami peningkatan pada siklus I sebesar $48 \%$ dengan kriteria sedang dan siklus II meningkat menjadi $86 \%$ tergolong kriteria tinggi. Aktivitas belajar siswa pada pembelajaran matematika tentang materi bangun datar melalui geometri datar juga mengalami peningkatan. Peningkatan tersebut terbukti pada siklus I sebesar $42 \%$ pada siklus II meningkat menjadi $86 \%$ tergolong kriteria tinggi. Peningkatan ini terjadi dimana siswa selalu memperhatikan kelemahannya dan berusaha untuk memperbaikinya terlihat pada tahap-tahap siklus yang selalu ada peningkatan.

Peningkatan hasil belajar siswa pada pembelajaran matematika tentang materi bangun datar menggunakan alat geometri datar terjadi peningkatan hasil belajar terbukti pada keseluruhan presentase rata-rata hasil belajar siklus I sebesar $61 \%$ dan siklus II sebesar $78 \%$. Dapat disimpulkan bahwa proses pembelajaran dinyatakan tuntas dan berhasil dalam penelitian menggunakan alat peraga geometri datar dengan nilai ketuntasan klasikal diatas $78 \%$.

\section{DAFTAR PUSTAKA}

Dahar. (2007). Teori-Teori Belajar. Bandung: P2LPTK.

Djamarah.2009. Strategi Belajar Mengajar. Jakarta: Rineka Cipta.

Hanafiah, Nanang \& Cucu Suhana. (2010). Konsep Strategi Pembelajaran. Bandung: Revika Aditama.

Jannah, E.N. (2016) Peningkatan Hasil Belajar Materi Bangun Datar Pada Siswa Kelas II SD Negeri Piring Melalui Media Papan Berpaku. Fakultas Keguruan dan Ilmu Pendidikan Universitas PGRI Yogyakarta.

Sanjaya, Wina. 2010. Pembelajaran dan Implementasinya Kurikulum Berbasis Kompetensi. Jakarta: Kencana Prenada Media Group.

Sardiman. 2006. Interaksi dan Motivasi Belajar. Jakarta: PT. Raja Grafindo Persada.

Sudijono, Anas. 2006. Pengantar Statistik Pendidikan. Jakarta: Raja Grafindo Persada 